\title{
Healthcare Professional's Perception and Attitude toward Pharmacist during Pharmacy Visit in Saudi Arabia
}

\author{
Yousef Ahmed Alomi ${ }^{1}$ **iD, Sarah Abdullah Al-Hathlool'2, Maryam Ibrahim Almulhim ${ }^{3}$, Amal Ali \\ Alashaq ${ }^{2}$, Yousef Aboshalaf ${ }^{3}$, Mytham Al-Ethan ${ }^{4}$ \\ ${ }^{1}$ The Former General Manager of General Administration of Pharmaceutical Care, the past head, National Clinical \\ Pharmacy and Pharmacy Practice, the past head, Pharmacy R and D Administration, Ministry of Health, Riyadh, \\ SAUDI ARABIA. \\ ${ }^{2}$ Clinical Pharmacy Staff, General Administration of Pharmaceutical Care, Ministry of Health, Riyadh, SAUDI ARABIA. \\ ${ }^{3}$ Head of Pharmacy Services King Fahad Hospital, Alhasa, SAUDI ARABIA. \\ ${ }^{4}$ Assistant head of Pharmacy Services, King Fahad Hospital, Alhasa, SAUDI ARABIA.
}

\section{Abstract}

Purpose: To explore the healthcare professional's perception and attitude toward pharmacist during pharmacy visit in Saudi Arabia. Methods: This is a 4-month cross-sectional survey of the healthcare professional's perception toward pharmacist. The survey consisted of two parts: the first part collects demographic information and the second part has 49 questions divided into four domains: (1) the first domain captures information regarding healthcare professionals' general perception of the pharmacist; (2) the second domain is regarding healthcare professionals' perception of pharmaceutical care services; (3) the third domain is about healthcare professionals' perception of visiting ambulatory care pharmacy; and (4) the fourth domain is regarding healthcare professionals perception of pharmacist's relationship and counseling skills. All type of healthcare professionals included in the study. We used the 5-point Likert response scale system to obtain responses of the participants. There were open- and close-ended questions. The survey was distributed through social media, namely, WhatsApp to more than one thousand healthcare professionals throughout the Kingdom of Saudi Arabia. The survey was distributed in an electronic format and this study analyzes and presents data regarding domain three, that is, healthcare professionals' perception of visiting ambulatory care pharmacy through the Survey Monkey system. Results: A total of 170 healthcare professionals responded to the survey. Of them, 150 (93.8\%) were Saudi and 10 (6.25\%) were non-Saudi professionals. There were 129 (75.9\%) female and $41(24.1 \%)$ male responders. Most of the healthcare providers were pharmacists $(81(47.65 \%))$, others $(33(19.41 \%))$, nurses $(27(15.88 \%))$ and physician $(23(13.53 \%))$. Most of the healthcare professional visited the pharmacy in the past 12 months $(53(31.36 \%))$ for more than 10 times, whereas the others $40(23.67 \%)$ visited at least 5-9 times. Most of the patients (143 (87.2\%)) spent less than 16 min waiting for the medication from the pharmacy. The average score of healthcare professional's general perception toward a pharmacist during pharmacy visit was 3.51. The statement "received all medications prescribed to me" received the highest score (4.05), whereas the statement "pharmacy's waiting area is located at the convenient place" received the lowest score (3.07). The average score of healthcare professional's perception toward a drug monitoring pharmacist during the pharmacy visit was 2.58 . The statement with the highest score was "the patient revived a copy of prescription contained medications" (2.99), whereas the statement with the lowest score was "the pharmacist gives follow-up call to the patient as prescribed" (1.86). The score for general evaluation of pharmacy visit was (3.31) with preference to visit the pharmacy or recommend it to patient's bothers or friends was (3.26). Conclusion: The healthcare professional's perception of a pharmacist during the pharmacy visit was good. Pharmacy's waiting area, medications reconciliation and adherences missed. Improving of healthcare providers' needs will augment healthcare professional's perceptions and raise healthcare provider's satisfaction during pharmacy visit.

Key words: Healthcare professional, Perception, Attitude, Pharmacist, Visit, Ministry of Health, Saudi Arabia.
Received: 23-10-2018;

Accepted: 11-12-2018

*Correspondence to:

Dr. Yousef Ahmed Alomi

The Former General Manager of General Administration of Pharmaceutical Care Head, National Clinical Pharmacy and Pharmacy Practice, Head, Pharmacy R and D Administration, Ministry of Health, P.O.BOX 100, Riyadh 11392, Riyadh, SAUDI ARABIA.

Phone no: +966504417712 Email: yalomi@gmail.com

DOI: 10.5530/ijpcs.2019.8.5

Copyright: ๑ the author(s),publisher and licensee International Journal of Pharmacology and Clinical Sciences. This is an open-access article distributed under the terms of the Creative Commons Attribution Non-Commercial License, which permits unrestricted noncommercial use, distribution, and reproduction in any medium, provided the original work is properly cited.

This is an open access article distributed under the terms of the Creative Commons Attribution-NonCommercial-ShareAlike 4.0 License

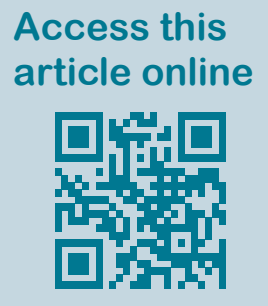

www.ijpcs.net 


\section{INTRODUCTION}

In general, patients visit the pharmacy as the last step of their healthcare management activities to purchase their medication. A patient might also be an academic student or be a healthcare professional. Thus, medications complete the therapeutic planning of a patient. Several studies have measured the level of satisfaction with respect to the pharmacy services in regular patients during the patients' visit to the pharmacy and obtained different responses from the patients. ${ }^{[1-4]}$ However, to the best of our knowledge, studies investigating the healthcare professionals' perception during pharmacy visit toward a pharmacist are scarce. ${ }^{[5-6]}$ Furthermore, there are no studies conducted in Saudi Arabia, the Gulf and Middle Eastern countries on the aforementioned topic. Therefore, in this study, we aimed to explore healthcare professionals' perception toward a pharmacist during pharmacy visit in the Kingdom of Saudi Arabia.

\section{METHODS}

This is a 4-month cross-sectional survey of healthcare professionals' perception toward a pharmacist. The survey consisted of two parts: the first part collects demographic information and the second part has 49 questions divided into four domains: (1) the first domain is regarding healthcare professionals' general perception toward the pharmacist; (2) the second domain captures healthcare professionals' perception regarding pharmaceutical care services; (3) the third domain is regarding healthcare professionals' perception regarding visiting ambulatory care; and (4) the fourth domain captures information regarding healthcare professionals perception toward the pharmacist's relationship and counseling skills. All types of healthcare professionals were included in this study. We used the 5-point Likert response scale system to obtain responses. There were open- and closeended questions. The survey was distributed through social media (WhatsApp) to more than one thousand healthcare professionals across the Kingdom of Saudi Arabia. A message reminder was sent to the healthcare professional after 2 weeks and an additional message reminder was sent to the healthcare professional after 4 weeks of distribution of the survey questionnaire. The survey was distributed in an electronic format and in this study, we analyzed the results of domain one primary or necessary information about healthcare professional's medication through Survey Monkey system.

\section{RESULTS}

A total of 170 healthcare professionals responded to the questionnaire. Of them, 150 (93.8\%) were Saudi and 10 (6.25\%) were non-Saudi professionals. There were 129 (75.9\%) female and $41(24.1 \%)$ male responders. Most of them were in the age group of 18-44 years (95.8\%) and were located in the regions of Riyadh $(69$ (41.6\%)), East Province (36 (21.7\%)) and Alhasa (26 (15.66\%)). The highest level of education among the responders was Bachelor degree (126 (76.4\%)) followed by Diploma (16 (9.7\%)). Most of the healthcare providers were pharmacists $(81(47.65 \%))$, others $(33(19.41 \%))$, nurses (27 (15.88\%)) and physician (23 (13.53\%)). Most of the healthcare professionals visited the pharmacy more than 10 times in the past 12 months (53 (31.36\%)), whereas the others $(40(23.67 \%))$ visited the pharmacy at least 5-9 times. Most of the healthcare professionals visited the pharmacy in the evening $(79(47.31 \%))$ and in the morning (54 (32.34\%)). Most of the patients (143 (87.2\%)) spent less than 16 min waiting for the medication from the pharmacy (Table 1). The average score of healthcare professional's general perception

\begin{tabular}{|c|c|c|}
\hline & $\begin{array}{l}\text { Response } \\
\text { Count }\end{array}$ & $\begin{array}{l}\text { Response } \\
\text { Percent }\end{array}$ \\
\hline \multicolumn{3}{|l|}{ Sex } \\
\hline Female & 129 & $75.9 \%$ \\
\hline Male & 41 & $24.1 \%$ \\
\hline Answered question & 170 & \\
\hline Skipped question & 0 & \\
\hline \multicolumn{3}{|l|}{ Nationality } \\
\hline Saudi & 150 & $93.75 \%$ \\
\hline Non-Saudi & 10 & $6.25 \%$ \\
\hline Answered question & 160 & \\
\hline Skipped question & 10 & \\
\hline \multicolumn{3}{|l|}{ Age } \\
\hline$<18$ & 0 & $0.00 \%$ \\
\hline $18-29$ & 127 & $75.60 \%$ \\
\hline $30-44$ & 34 & $20.24 \%$ \\
\hline $45-59$ & 7 & $4.17 \%$ \\
\hline $60+$ & 0 & $0.00 \%$ \\
\hline Answered question & 168 & \\
\hline Skipped question & 2 & \\
\hline Type of visit & $\begin{array}{l}\text { Response } \\
\text { Count }\end{array}$ & Response Percent \\
\hline Physician & 23 & $13.53 \%$ \\
\hline Dentist & 4 & $2.35 \%$ \\
\hline Pharmacist & 81 & $47.65 \%$ \\
\hline Nurse & 27 & $15.88 \%$ \\
\hline Others & 33 & $19.41 \%$ \\
\hline
\end{tabular}




\begin{tabular}{|c|c|c|}
\hline & $\begin{array}{l}\text { Response } \\
\text { Count }\end{array}$ & $\begin{array}{l}\text { Response } \\
\text { Percent }\end{array}$ \\
\hline Answered question & 170 & \\
\hline Skipped question & 0 & \\
\hline $\begin{array}{l}\text { In the last } 12 \text { months, the number of } \\
\text { times visited the pharmacy }\end{array}$ & $\begin{array}{l}\text { Response } \\
\text { Count }\end{array}$ & Response Percent \\
\hline None & 6 & $3.55 \%$ \\
\hline 1 time & 15 & $8.88 \%$ \\
\hline 2 & 21 & $12.43 \%$ \\
\hline 3 & 19 & $11.24 \%$ \\
\hline 4 & 15 & $8.88 \%$ \\
\hline 5 to 9 & 40 & $23.67 \%$ \\
\hline 10 or more times & 53 & $31.36 \%$ \\
\hline Answered question & 169 & \\
\hline Skipped question & 1 & \\
\hline Time of Visiting the Pharmacy & $\begin{array}{l}\text { Response } \\
\text { Count }\end{array}$ & Response Percent \\
\hline Morning & 54 & $32.34 \%$ \\
\hline Evening & 79 & $47.31 \%$ \\
\hline Night & 34 & $20.36 \%$ \\
\hline Answered question & 167 & \\
\hline Skipped question & 3 & \\
\hline $\begin{array}{l}\text { The waiting time to get the } \\
\text { medications }\end{array}$ & $\begin{array}{l}\text { Response } \\
\text { Count }\end{array}$ & Response Percent \\
\hline$<5$ & 70 & $42.68 \%$ \\
\hline $5-10$ & 53 & $32.32 \%$ \\
\hline $11-15$ & 20 & $12.20 \%$ \\
\hline
\end{tabular}

\begin{tabular}{|c|c|c|}
\hline & $\begin{array}{l}\text { Response } \\
\text { Count }\end{array}$ & $\begin{array}{l}\text { Response } \\
\text { Percent }\end{array}$ \\
\hline $16-20$ & 7 & $4.27 \%$ \\
\hline $21-25$ & 3 & $1.83 \%$ \\
\hline $26-30$ & 3 & $1.83 \%$ \\
\hline $31-35$ & 0 & $0.00 \%$ \\
\hline $36-40$ & 1 & $0.61 \%$ \\
\hline $41-45$ & 1 & $0.61 \%$ \\
\hline $46-50$ & 0 & $0.00 \%$ \\
\hline $51-55$ & 1 & $0.61 \%$ \\
\hline $56-60$ & 1 & $0.61 \%$ \\
\hline More than 60 & 4 & $2.44 \%$ \\
\hline Answered question & 164 & \\
\hline Skipped question & 6 & \\
\hline Educational levels & $\begin{array}{l}\text { Response } \\
\text { Count }\end{array}$ & Response Percent \\
\hline Doctorate degree & 6 & $3.64 \%$ \\
\hline Master degree & 8 & $4.85 \%$ \\
\hline Bachelor Degree & 126 & $76.36 \%$ \\
\hline Diploma & 16 & $9.70 \%$ \\
\hline High school & 8 & $4.85 \%$ \\
\hline Intermediate School & 0 & $0.00 \%$ \\
\hline Primary School & 1 & $0.61 \%$ \\
\hline Not educated & 0 & $0.00 \%$ \\
\hline Answered question & 165 & \\
\hline Skipped question & 5 & \\
\hline
\end{tabular}

\begin{tabular}{|l|c|c|c|c|c|c|c|}
\hline Table 2: The general perception of healthcare provider toward the pharmacist during his visit. \\
\hline Answer Options & $\begin{array}{l}\text { Strongly } \\
\text { agree }\end{array}$ & Agree & Neutral & Disagree & $\begin{array}{l}\text { Strongly } \\
\text { disagree }\end{array}$ & $\begin{array}{l}\text { Rating } \\
\text { Average }\end{array}$ & $\begin{array}{l}\text { Response } \\
\text { Count }\end{array}$ \\
\hline $\begin{array}{l}\text { 1. Pharmacy Location Domain } \\
\text { Is the pharmacy conveniently located }\end{array}$ & 21 & 80 & 40 & 19 & 3 & 3.60 & 163 \\
\hline $\begin{array}{l}\text { 2. Pharmacy Waiting Area Domain } \\
\text { Is the waiting area of pharmacy conveniently located? }\end{array}$ & 16 & 45 & 48 & 42 & 12 & 3.07 & 163 \\
\hline $\begin{array}{l}\text { 3. Pharmacy Waiting Time Domain } \\
\text { The amount of time it takes to get a prescription filled at your } \\
\text { pharmacy is very appropriate. }\end{array}$ & 18 & 73 & 42 & 22 & 8 & 3.44 & 163 \\
\hline $\begin{array}{l}\text { 4. Medication Availability Domain } \\
\text { Have you received all the medications, that has prescribed } \\
\text { to you }\end{array}$ & 52 & 83 & 20 & 9 & 2 & 4.05 & 166 \\
\hline $\begin{array}{l}\text { 5. You have received a prescription refill of your medicines to } \\
\text { continue dispensing from pharmacy directly next months. }\end{array}$ & 23 & 61 & 45 & 24 & 11 & 3.37 & 164 \\
\hline $\begin{array}{l}\text { answered question } \\
\text { skipped question }\end{array}$ & & & & 164 \\
\hline
\end{tabular}

toward a pharmacist during pharmacy visit was 3.51 . The statements "received all medications prescribed to me" and "pharmacy is located at convenient spot" received highest scores (4.05 and 3.6, respectively). The statement "pharmacy's waiting area is convenient" received the lowest score (3.07). The average score of healthcare professional's perception toward the pharmacist with drug monitoring during the pharmacy visit was 2.58 . The statement with the highest score was "the patient revived a copy of prescription medications" (2.99), whereas the statement with the lowest score was "the pharmacist gives follow-up call to the patient as prescribed" (1.86). The general evaluation of pharmacy visit was 3.31 with the preference of the patient to visit the pharmacy or recommending it to their bothers or friends was 3.26 (Tables 2 and 3). 


\begin{tabular}{|c|c|c|c|c|c|c|c|}
\hline Answer Options & $\begin{array}{l}\text { Strongly } \\
\text { agree }\end{array}$ & Agree & Neutral & Disagree & $\begin{array}{l}\text { Strongly } \\
\text { disagree }\end{array}$ & $\begin{array}{l}\text { Rating } \\
\text { Average }\end{array}$ & $\begin{array}{l}\text { Response } \\
\text { Count }\end{array}$ \\
\hline $\begin{array}{l}\text { 1. Medication Reconciliation Domain } \\
\text { Pharmacist uses information about you } \\
\text { previous conditions/drugs when assessing } \\
\text { your drug therapy. }\end{array}$ & 14 & 36 & 43 & 44 & 27 & 2.79 & 164 \\
\hline $\begin{array}{l}\text { 2. You have received a copy of prescription } \\
\text { contains all medications prescribed to you } \\
\text { and may use during outpatient clinic or } \\
\text { emergency when necessary. }\end{array}$ & 16 & 41 & 46 & 37 & 19 & 2.99 & 159 \\
\hline $\begin{array}{l}\text { 3. Medication Adherence Domain } \\
\text { The pharmacist asks about medication } \\
\text { compliance }\end{array}$ & 11 & 32 & 41 & 55 & 23 & 2.71 & 162 \\
\hline $\begin{array}{l}\text { 5. Pharmacy Recommended to other } \\
\text { patients Domain Prefer to visit the pharmacy } \\
\text { again or recommend to your brothers or } \\
\text { friends }\end{array}$ & 19 & 46 & 68 & 16 & 13 & 3.26 & 162 \\
\hline $\begin{array}{l}\text { 6. Overall Patient Satisfaction with } \\
\text { Pharmacy Services Domain } \\
\text { Your general evaluation for the } \\
\text { pharmaceutical care is very satisfied }\end{array}$ & 16 & 55 & 63 & 17 & 10 & 3.31 & 161 \\
\hline \multicolumn{7}{|l|}{ answered question } & 165 \\
\hline skipped question & & & & & & & 5 \\
\hline
\end{tabular}

\section{DISCUSSION}

All methods of implementation of pharmaceutical care were based on the American Society of HealthSystem Pharmacists. ${ }^{[7-8]}$ The pharmacist provides the pharmaceutical care to the patients and healthcare providers and provides them with the required medication. The pharmacy administration at the Ministry of Health established the regulations for the patient satisfaction of pharmacy services but did not establish any regulation for healthcare professionals' satisfaction of pharmacy services during the pharmacy visit. ${ }^{[9-10]}$ This might be because they expected that both features are the same. Furthermore, so far, no study has reported the level of satisfaction of pharmacy services or perception of healthcare providers toward pharmacists in Saudi Arabia. In this study, the authors tried to explore healthcare professionals' including physician, pharmacist and nurse's perception regarding pharmacy services during their visit to the pharmacy. The results show that healthcare provider's general perception toward a pharmacist during pharmacy visit was neutral or not adequate. This result might be due to the pharmacy's waiting area not being available all the time to the healthcare professionals or it might be because there is no waiting area in most hospitals or community pharmacies. Furthermore, at more than one-third of the pharmacies, there is no refill prescription provided by the healthcare providers. Despite this, the availability of medications and location of pharmacy had shown some advantages in some pharmacies. The waiting time at the pharmacy is acceptable to the healthcare professionals, as the pharmacy's staff provide them particular attention as they will have others medical duties to attend. The results of the healthcare provider's perception toward the pharmacist's drug monitoring activity were found to be inadequate. This might be because the pharmacist was unable to give a follow-up call to the patient after dispensing medications and medications adherence has not been implemented as tools to follow up patient's drug therapy. Furthermore, the medication reconciliation guideline has not been implemented at most of the pharmacies especially at the community pharmacies. Similar results have been reported by Al-Arifi regarding patient perception and Oshima et al. regarding healthcare providers. ${ }^{[4,6]}$ However, Al-Arifi reported lower values of medication adherence as perceived by patients. ${ }^{[4]}$ Other results of the current study could not compare with the previous study because similar investigation not done. The overall general perception of healthcare professionals toward pharmacist during pharmacy visit was almost neutral or inferior. In addition, one-third of the professionals do not recommend their family or friends to visit the pharmacy. This may be because the level of the current practice of pharmacy professionals or the pharmacy services not clear or understood very well by them. 


\section{CONCLUSION}

The healthcare professionals' perception of pharmacists during the pharmacy visit was neutral with the weakness of drug therapy monitoring. The pharmacy department should implement medications reconciliation and medications adherence system to improve the pharmacy services in the Kingdom of Saudi Arabia.

\section{ACKNOWLEDGMENT}

None.

\section{CONFLICT OF INTEREST}

None.

\section{ABBREVIATIONS}

KSA: Kingdom of Saudi Arabia; MOH: Ministry of Health; CBAHI: Saudi Central Board for Accreditation of Healthcare Institutions; USA: United States of America.

\section{ORCID ID}

Yousef Ahmed Alomi (D) https://orcid.org/0000-00031381-628X

\section{REFERENCES}

1. Merks P, Świeczkowski D, Jaguszewski MJ. Patients' perception of pharmaceutical services available in a community pharmacy among patients living in a rural area of the United Kingdom. Pharm Pract (Granada). 2016;14(3).

2. Khan MU, Khan AN, Ahmed FR, Feroz Z, Rizvi SA, Shah S, et al. Patients' opinion of pharmacists and their roles in health care system in Pakistan. J Young Pharm. 2013;5(3):90-4.

3. Shiyanbola OO, Mott DA, Croes KD. The structural and process aspects of pharmacy quality: older adults' perceptions. Int J Clin Pharm. 2016;38(1):96-106.

4. Al-Arifi MN. Patients' perception, views and satisfaction with pharmacists role as health care provider in a community pharmacy setting at Riyadh, Saudi Arabia. Saudi Pharm J. 2012;20(4):323-30.

5. Schindel TJ, Yuksel N, Breault R, Daniels J, Varnhagen S, Hughes CA. Perceptions of pharmacists' roles in the era of expanding scopes of practice. Res Soc Adm Pharm. 2017;13(1):148-61.

6. Oshima S, Senoo K, Negishi A, Akimoto H, Kutsuma N, Juni K, et al. Identification of the Discrepancies between Pharmacist and Patient Perception of the Pharmacist's Role as an Advisor on Drug Therapy Based on Social Science Theory. Biol Pharm Bull. 2016;39(39):313-22.

7. American Society of Health-System Pharmacist. ASHP Statement on Pharmaceutical Care. Am J Hosp Pharm. 1993;50:1720-3.

8. American Society of Health-System Pharmacists. ASHP guidelines on a standardized method for pharmaceutical care. Am J Heal Pharm. 1996;53(14):17136.

9. Alomi YA. Patient satisfaction of pharmaceutical care system at Ministry of Health in Saudi Arabia. BAOJ Pharm Sci. 2016;2:19.

10. Alomi YA, Kurdy L, Aljarad Z, Basudan H, Almekwar B. Patient satisfaction of pharmaceutical care of primary care centers at Ministry of Health in Saudi Arabia. J Pharm Pract Community Med. 2016;2(3):79-87.

Cite this article as: Alomi YA, Al-Hathlool SA, Almulhim MI, Alashaq AA, Aboshalaf Y, Al-Ethan M. Healthcare Professional's Perception and Attitude toward Pharmacist during Pharmacy Visit in Saudi Arabia. Int J Pharmacol. Clin. Sci. 2019;8(1):21-5. 